Binghamton University

The Open Repository @ Binghamton (The ORB)

\title{
Unintelligibility as discourse accessibility in a Senegalese ethnomedical encounter
}

Sabina Perrino

sperrino@binghamton.edu

Follow this and additional works at: https://orb.binghamton.edu/anthropology_fac

Part of the Anthropology Commons

\section{Recommended Citation}

Perrino, Sabina, "Unintelligibility as discourse accessibility in a Senegalese ethnomedical encounter" (2007). Anthropology Faculty Scholarship. 38.

https://orb.binghamton.edu/anthropology_fac/38

This Article is brought to you for free and open access by the Anthropology at The Open Repository @ Binghamton (The ORB). It has been accepted for inclusion in Anthropology Faculty Scholarship by an authorized administrator of The Open Repository @ Binghamton (The ORB). For more information, please contact ORB@binghamton.edu. 


\title{
Unintelligibility as discourse accessibility in a Senegalese ethnomedical encounter*
}

\author{
SABINA PERRINO
}

\section{Abstract}

'Unintelligibility' is not an on-off phenomenon, but rather a processual, bydegrees, and phase-relative phenomenon, as recent literature has demonstrated. With these facts in mind, this article approaches 'unintelligibility' in terms of discourse 'accessibility', emphasizing especially how 'access' is regulated in multiple ways (not only through language), and how it centrally involves changes in participation structure. Using a Senegalese ethnomedical encounter as my focus, I examine how the verbal and nonverbal regulation of accessibility helps bring into play forms of mediation, where the interactant conferring access offers to the patient both expert knowledge and contact with incorporeal beings. During a divination phase, a phase of maximum inaccessibility, contact with these beings comes to be presupposed in the healer's discourse as he positions himself as a mediator who stands between the patient and the unseen sources of advice and curative power. By making the inaccessible accessible over phases of the encounter, the healer both invokes expert knowledge and constructs an interdiscursive figure, a virtual 'speech-chain' structure, in which his verbal (and nonverbal) contributions become links designed to convey curative power and blessings from incorporeal beings to the patient in the immediate speech event.

Keywords: unintelligibility; interdiscursivity; ethnomedicine; ritual; mediation; Senegal.

\section{Introduction: 'Unintelligibility' as discourse accessibility}

In her article on identity in possession and spirit mediumship, Judith Irvine remarked that '[i]ntelligibility, it turns out, is not a yes-or-no matter' (1982: 244). To expand on this point, it is not a yes-or-no matter for a number of reasons that have been noted in the literature. First, discourse 
'unintelligibility' often varies across categories of ritual participants and informants, as Malinowski (1965 [1935]) long ago noted. In volume II of Coral Gardens and Their Magic, he acknowledged that the (un)intelligibility of the words and expressions that make up magic's lexical repertoire varies with the competence of individuals; a 'competent commentator' may be able to provide glosses (1965 [1935]: 222), a point many after him have similarly made (cf. Tambiah 1968; Kearney 1977; Hinton 1980; Powers 1986; Wirtz 2005). Second, discourse may be unintelligible in one respect but intelligible in another. For example, in cases where lexical elements of a register cannot be semantically glossed, which is the prototypical case of unintelligibility, they can still be made meaningful by co-occurring verbal and nonverbal signs, by the indexical value of the register itself (e.g., merely knowing that a highly marked register is being spoken), or by iconicity of the acoustic signal or poetic qualities of the discourse (see Samarin 1972; Hinton 1980). Third, intelligibility is often phase-relative (Wirtz 2005), in the sense that an opaque lexical register, for example, may be used during certain phases of a ritual event but not others. Fourth and finally, the unintelligible is often made intelligible as the event unfolds, by ritual specialists who gloss or translate opaque discourse (Briggs 1996), or through the multi-party negotiation of meaning (Schieffelin 1985). For all these reasons, I refer in this article not to 'unintelligibility' per se, but to the regulation of discourse 'accessibility' among participants and across phases of the ritual event. 'Accessibility', unlike the term 'unintelligibility', suggests a socially distributed phenomenon, which varies with the competence of individuals (issue one, above); it suggests a by-degrees phenomenon, allowing for cases of partial intelligibility (issue two); it suggests that 'access' may be temporally variable, occurring during certain phases of discourse and not others (issue three); and it suggests that discourse that is momentarily inaccessible can be made accessible by and for interactants (issue four).

This terminological change from '(un)intelligibility' to discourse 'accessibility' has two further entailments that I will especially examine in this article. This focus on the regulation of discourse 'accessibility' in ritual discourse requires a consideration of social-interactional participation structures and an expansion into nonverbal behavior. With respect to participation structures, so-called 'unintelligibility' involves more than the individual experiencer's incapacity (or partial capacity) to cognize a given linguistic expression, register, or code. In discursive interaction, this cognitive event typically co-occurs with changes in participation structure, that is, changes in 'engagement, and therefore coengagement, of social actors in an ongoing activity' (Hanks 1996: 160; emphasis in the original), and these social-interactional changes are important for understanding 
what changes in discourse accessibility 'do', pragmatically speaking, as I will later demonstrate.

Second, and finally, I will show how this approach to discourse accessibility entails an expansion into nonverbal modalities, because 'access' is managed in multiple ways, not only through language. This expansion into multimodal sign behavior marks a turn from the study of decontextualized speech registers, especially lexical registers on which Malinowski (1965 [1935]) classically focused, and on which some researchers continue to depend. Powers (1986), for example, focuses on semantically opaque lexical items within the religious registers of the Lakota-speaking Oglala of South Dakota, and in his discussion of Cuna Indians of Panama, Severi (1993: 169-170) identifies how the spirits' register is lexically differentiated from human registers (cf. Du Bois 1992). ${ }^{1}$ Some researchers have indeed moved beyond lexical repertoires, by considering, for example, marked syntax, voice quality, and prosody (Samarin 1972: 78 et passim), and I build on this work by extending it to nonverbal behavior.

In this article, I analyze a video-recorded Senegalese ethnomedical encounter and show how the ritual specialist regulates accessibility through verbal and nonverbal means. I show, in particular, how the performance of unintelligibility cross-cuts semiotic modalities, how it is phase-relative, and how previously inaccessible discourse is made accessible for the patient, all of which brings about important changes in participation. In terms of what these changes accomplish, I argue that the healer, through the cross-modal regulation of discourse accessibility, engages in two distinct but closely related forms of mediation that are laminated one onto the other. The first form of mediation involves the healer's role as an ethnomedical expert, where he offers the patient the benefit of the healer's privileged knowledge. The second form of mediation consists of a virtual, interdiscursive 'speech chain' (Agha 2003: 247), in which the healer therapeutically offers the patient access to incorporeal agents that aid in the cure. He reflexively locates the event of healing in a historicalcosmographic space, where the healer positions himself as a mediator who stands between the patient and the healing power of spirits, of the Prophet Mohammed and, ultimately, of Allah.

\section{Setting}

The ethnomedical encounter I analyze below is between a traditional healer, or sërĩn, whose name is Abdoulaye Siñaañ (hereafter, Sërĩn Siñaañ), ${ }^{2}$ and a patient, Djafara Sedikhou Fofana (hereafter, Mr. Fofana) ${ }^{3}$ (see Figure 1). 


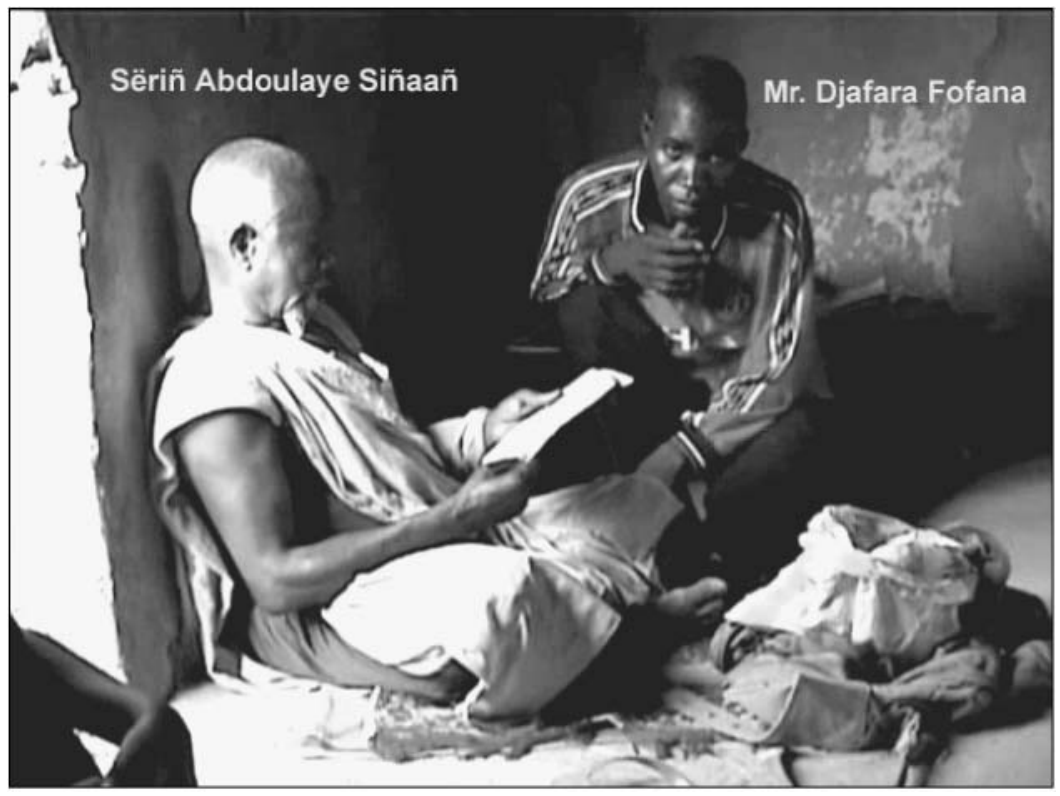

Figure 1. Sërĩn Abdoulaye Siñaañ and Mr. Djafara Fofana during the ethnomedical encounter (image extracted from original video footage)

The title sërĩn, or marabout in French, denotes high-status religious personages within the Sūfi brotherhoods of Senegal. Though sërĩñs fill a wide range of roles, including that of Islamic priest, judge, and Qur'an instructor (Monteil 1964: 121-148; Cruise O’Brien 1971; Copans 1988; Cruise O'Brien and Coulon 1988; Fassin 1992: 65-82), Senegalese especially value their competence in performing curing rituals.

The encounter occurred in June 2000 in Koungheul, a village located 336 kilometers from Dakar in east-central Senegal. This event, which was videotaped with Sërīñ Siñaañ's permission, lasted 20 minutes and $15 \mathrm{sec}-$ onds, most of which (approximately 15 minutes) consisted of a phase in which the healer prepared medicine for the patient (for a detailed analysis of this encounter, see Perrino 2002). The conversation between the healer and the patient was conducted entirely in Wolof. ${ }^{4}$ As indicated in Table 1 , the ethnomedical encounter can be roughly divided into twelve textual phases, though I will focus on the fifth and seventh phases, the 'Diagnosis and prescription through divination' phase (from line 142 to line 144d), and the 'Recitation of the Hadith' phase (from line 157a to line $160 \mathrm{~m}$ ), respectively; these were the phases in which the healer regulated the accessibility of his discourse to great effect. ${ }^{5}$ 
Table 1. Synopsis of ethnomedical encounter

\begin{tabular}{|c|c|c|c|c|c|c|c|c|c|c|c|c|}
\hline Start line & 1 & 67 & 85 & 95 & 142 & 145 & $157 \mathrm{a}$ & \multirow[t]{2}{*}{ [Not transcribed] } & 161 & 173 & $180 \mathrm{c}$ & 185 \\
\hline End line & 66 & 84 & 94 & 141 & $144 d$ & 156 & $160 \mathrm{~m}$ & & 172 & $180 \mathrm{~b}$ & $184 \mathrm{c}$ & 191 \\
\hline $\begin{array}{l}\text { Phase of } \\
\text { encounter }\end{array}$ & 志: & $\begin{array}{l}\stackrel{0}{0} \\
\stackrel{0}{0} \\
\stackrel{0}{0}\end{array}$ & 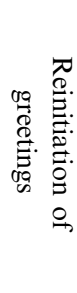 & $\begin{array}{c}\text { Disclosure of } \\
\text { symptoms }\end{array}$ & $\begin{array}{l}\text { Diagnosis and } \\
\text { prescription } \\
\text { through } \\
\text { divination }\end{array}$ & 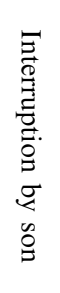 & $\begin{array}{l}\text { Recitation } \\
\text { of Hadith }\end{array}$ & $\begin{array}{c}\text { Break: } \\
\text { Preparation of } \\
\text { medicine }\end{array}$ & 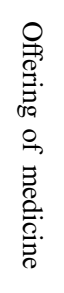 & 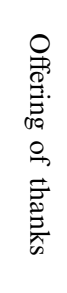 & 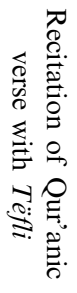 & $\begin{array}{l}T \\
\stackrel{T}{0} \\
\sum_{0}^{0} \\
\stackrel{0}{=}\end{array}$ \\
\hline Duration & $\begin{array}{l}\stackrel{\ominus}{\dot{\phi}} \\
\underset{\infty}{\dot{\infty}}\end{array}$ & 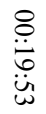 & $\begin{array}{l}\stackrel{8}{\dot{\delta}} \\
\stackrel{\operatorname{\theta }}{0}\end{array}$ & $00: 50: 38$ & 01:06:60 & 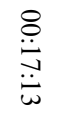 & 01:24:94 & $14: 36: 70$ & 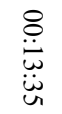 & $\begin{array}{l}\stackrel{8}{0} \\
\dot{0} \\
\ddot{U} \\
\text { ù }\end{array}$ & $\begin{array}{l}\stackrel{8}{\dot{\omega}} \\
\stackrel{9}{\dot{v}}\end{array}$ & $\begin{array}{l}\stackrel{8}{\dot{\theta}} \\
\ddot{\leftrightarrow} \\
\ddot{\omega}\end{array}$ \\
\hline
\end{tabular}

Total duration: 20 min., $14.78 \mathrm{sec}$.

The shaded areas indicate the phases of the ethnomedical encounter analyzed in this article. 


\section{Divination and recitation of the Hadith}

In Senegalese ethnomedical encounters, healers typically try to contact one or more incorporeal agents using divination (cf. Zempléni 1966, 1977, 1978; Dupire 1994; Kalis 1997; Perrino 2002). These agents may be ancestors, incorporeal beings with an understood genealogical relation to the patient or healer. Or they may be certain classes of spirits, especially those termed jinnes and rabs. In a follow-up interview with Sërĩn Siñaañ, he acknowledged that he tried to contact spiritual beings during this phase of the ethnomedical encounter, but he would not disclose exactly how he did this or which beings he tried to contact. As with most sëriñns, he kept this type of information secret.

As to how sërĩns cultivate and maintain relations with spiritual beings, there is, in general, a great deal of variability. During fieldwork in 2003, for example, Sërīñ Keïta Seidi, a healer living in the suburbs of Dakar, recounted how he established a connection with a female jinne named Mariama. Mariama had been the same jinne used by his father. His father transmitted his knowledge and experience with Mariama to Sërĩn Seidi when he was young. To introduce him to the spirit, his father brought him for an entire week to one of their family houses in the Casamance in southern Senegal, the location where his father first encountered the spirit. After first encountering Mariama in the house, Sërīñ Seidi then spent many nights in prayer, invoking Mariama's name with his prayer beads so as to develop the ability to draw consistently on her power during his healing rituals. Another healer, Sërĩn Moussa Nguer, living in Dakar, described how he established a unique relationship with an 'esprit de la mer' (spirit of the sea) of Dakar. Unlike the case of Sërīn Seidi, he discovered this spirit on his own. To harness its power, Sërīñ Nguer enters into closed retreats in his apartment, often combining prayer and invocation of the spirit (performed with the use of the prayer beads) with the sacrifice of a cow, sheep, cock, or hen, a sacrifice which he performs on the beach near the abode of this spirit.

Senegalese healers are said to possess varying degrees of mystical power, or baraka, through which they can contact these incorporeal agents, but the precise ritual technologies used to establish contact are closely guarded. This knowledge, together with other forms of expert knowledge (of plants, texts, therapies, and so forth), collectively termed xam-xam in Wolof, is indexed by the healer during the encounter itself, as I will show. Through indexing his command of this knowledge, the healer implicitly positions him as a 'mediator' who stands between the patient and esoteric knowledge. A second and related form of mediation is brought into play through the regulation of discourse accessibility as well, 
and this is the healer's capacity to communicate with incorporeal spirits. In what follows, I will show how these two forms of mediation, both brought about through the regulation of discourse accessibility, are central to the way this ethnomedical encounter operates.

During the divination phase, healers frequently try to identify passages from the Hadith and the Qur'an, passages to be used in combination with herbal remedies to cure the patient. The Hadith are believed to have derived from the teachings of the Prophet Mohammed. Unlike the Qur'an, which is held to be a transcendent text whose verses act directly on the patient, the Hadīth's denotational content can be translated and recontextualized. In this encounter, divination is the most inaccessible phase, in which the healer uses unintelligible incantations to establish contact with spirits who can help diagnose the patient and identify a cure. As the healer utters this inaccessible discourse, he decreases loudness, redirects his eye-gaze away from the patient, and stops uttering minimal responses. That is, he cross-modally transforms the participation structure by ceasing signs of mutual monitoring and involvement relative to previous phases of discourse, as I will later demonstrate. Before the divination phase began, in fact, the sërĩ appears highly attuned and responsive to the patient. This is evident in the many minimal responses uttered by the serriñ. During the disclosure of symptoms phase (lines 95-141), thirteen of the sëriñn's 23 utterances are minimal responses (i.e., $\mathrm{mm}$ ), and seven are assent responses of 'yes' (in Wolof, waaw). The patient does most of the talking, but in 20 of the sëriñn's 23 utterances, he signals involvement and attention through his backchannel behavior, as shown in the transcript below. ${ }^{6}$

(1) (Transcript segment 1)

Patient (P); Sérĩ̃ (S)

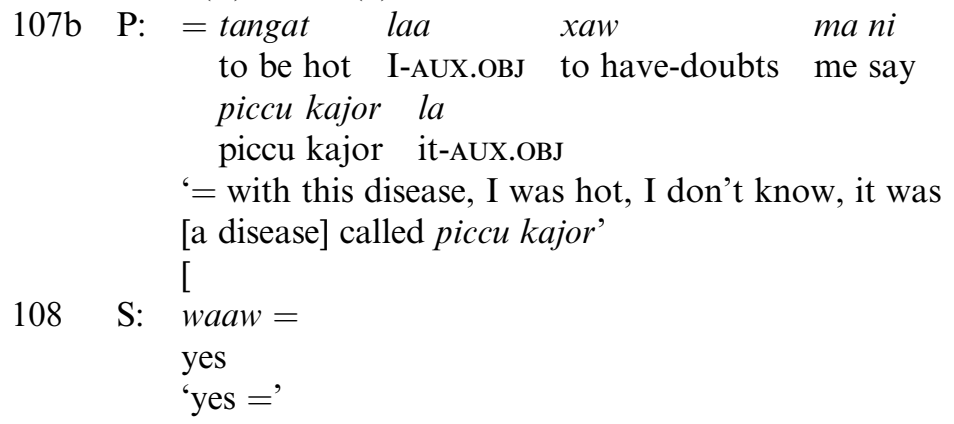

$109 \mathrm{P}:=$ biir buy metti sonnal ma stomach-SUBJ the-CLSF-DIST-CNTV hurt make tired me 
torop $\quad$ daal $=$ too much actually

'= my stomach hurts and it also makes me feel very tired ='

$110 \mathrm{~S}: \quad=$ waaw $=$ yes

$'=$ yes $=$

111 P: = kooku

benn la.

that-one-CLSF-SG-DIST one it-AUX.OBJ

'= that is the first problem.'

\{The SÉRĨĨ GAZES DOWNWARD AND A TENTH OF A SECOND LATER HE IS FOLLOWED BY THE PATIENT\}

$112 \mathrm{~S}: \mathrm{mm}$

$\mathrm{mm}$

'mm'

$113 \quad$ P: (0.54) si:.:. ñarel bi

so- second the-CLSF-SG-PROX

'(0.54) so::.:: the second one [i.e., problem]'

\{THE SÉRĪ̃̃ REESTABLISHES EYE CONTACT WITH THE PATIENT, AND THE PATIENT, WITH EYES STILL DOWNWARD, BEGINS TO STROKE HIS HEAD WITH HIS RIGHT HAND $\}$

114 S: $\quad(0.16) \mathrm{mm}$

$\mathrm{mm}$

'(0.16) mm'

115 P: (0.32) ci sama wallu liggéey la daal = in my frame job it-AUX.OBJ actually '(0.32) it really has to do with my work environment'

$116 \mathrm{~S}:=m m$ $\mathrm{mm}$

$'=\mathrm{mm}$ '

\{THE PATIENT RE-ESTABLISHES EYE CONTACT WITH THE HEALER\}

$117 \mathrm{a}$ P: $\quad$ :: h sama liggéey tusur - bu man ñewe:: uh my job always when I-AUX.SUBJ come $c i:$ :

in-CLSF-SG-PROX

'u::h my job [is] always- when I co::me to::'

117b (0.23) bërebu liggéeykay bi daal = office workplace the- CLSF-SG-PROX actually '(0.23) my workplace, actually $=$ '

$118 \mathrm{~S}: \quad=$ waaw $=$ yes

$'=$ yes $='$

P: $\quad(0.80) b u$

maay

$x \ddot{e} y$ $k \ddot{e r}$ when I-AUX.SUBJ-CNTV leave-in-the-morning house 


$$
g a=
$$

the- CLSF-SG-DIST

120

' $(0.80)$ when I leave the house in the morning to go to work ='

$[\ldots]$

$\mathrm{S}: \quad=m m=$

$\mathrm{mm}$

$'=\mathrm{mm}='$

However, when the patient begins to summarize his problems at the end of this phase (line 135), the sërĩn shifts his gaze: he turns his gaze away from the patient and re-directs it down toward the prayer beads in his hand in front of him. The patient continues to talk, and the sërĩ continues to offer minimal responses, but now in a lower volume (see in particular lines 138 and 140).

(2) (Transcript segment 2)
$133 \mathrm{P}:$ = duma sawar sama xeel du nekk ci I-AUX.NEG be-active my spirit not to-be in-CLSF-SG-PROX liggéey bi
job the-CLSF-SG-PROX
' $=\mathrm{I}$ am not active because my heart is not in my job'

$134 \mathrm{~S}: \quad(0.23) \mathrm{mm}=$

$$
\mathrm{mm}
$$

'(0.23) $\mathrm{mm}='$
$135 \mathrm{P}:=$ man ni daal ñaari soxla
I-AUX.EMPH say actually two problem $y i=$ the-CLSF-PL-PROX
'= I really think that I [have] two problems ='

$136 \mathrm{~S}:=m m \mathrm{hm}$

$\mathrm{mm} \mathrm{hm}$

$'=\mathrm{mm} \mathrm{hm}$ '

\{SËRĨN SIÑAAÑ GLANCES DOWN AT THE ROSARY IN HIS HAND, AND THE PATIENT PEERS UP AT HIM $\}$

137 P: (0.24) suma ñëwee bu sobe Yàlla $=$ if I-AUX.SUBJ come if want Allah

'(0.24) if I come [to you], if Allah wills [it] ='

$138 \mathrm{~S}: \quad={ }^{\circ}$ waa $^{\circ}=$ yes

$'={ }^{\circ} \mathrm{yes}^{\circ}=$ '
$\mathrm{P}:=$ maa diis la
ko $\quad$ daal $=$ I-AUX.SUBJ submit you-AUX.OBJ it actually

$'=$ I just submit it [i.e., my health issue] to you $=$ ' 

$140 \mathrm{~S}:=$ waaw baax $n a=$ yes good it-AUX.SUBJ $'=$ yes, $\operatorname{good}=$ '
141 P:

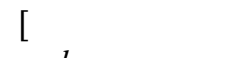
u::h nga dimbali ma
uh you-AuX.SuBJ help me
$c i$.
here-CLSF-SG-PROX
' $\mathrm{u}: \mathrm{h}$ help me here [with these problems of mine].'

\{THE PATIENT BEGINS TO SHIFT HIS KNEELING POSITION A BIT $\}$

$[\ldots]$

As the divination phase begins, Sërĩn Siñaañ murmurs an incantation while rubbing the prayer beads with both hands, and he then asks the patient to choose a bead. After the patient selects the bead, the sërĩn stops signaling the same degree of involvement vis-à-vis the patient, and severely restricts access to his speech. He does this by again reciting an acoustically unintelligible (i.e., inaudible) incantation as he counts his prayer beads and by re-directing his gaze away from the patient and toward the prayer beads in his hands. The patient covers his eyes for a few seconds as well, thus keeping his gaze away from the sërĩ and from the prayer beads (see Figure 2). In short, the default etiquette for co-presence (mutual monitoring, and so forth [see Goffman 1963]) maintained earlier in the encounter (and re-established after this phase) seems momentarily suspended. During the subsequent Hadith recitation phase, the participation structure returns to its previous state: signs of involvement and mutual monitoring resume between the patient and the sëriñ. The patient begins to nod his head, for example, at lines $157 \mathrm{e}, \mathrm{i}, \mathrm{m}, \mathrm{n}, \mathrm{f}$, and $\mathrm{h}$.

After approximately 30 seconds of counting his prayer beads, the sërĩn utters a phrase in an audible volume, the phrase $b a$ bu salaasa; by itself, this sentence-partial remains unintelligible for the patient, indexing, in part, the healer's expert knowledge. In fact, $b a$ bu salaasa is the initial line of the Hadith that he then goes on to recite for the patient. By asking the patient to choose a bead, and by 'mechanically' (Wilce 2001: 195) counting back the prayer beads until he reaches the bead that was chosen by the patient, the sërĩn continues to index expert knowledge, but now invokes a second form of mediation, that is, the virtual, cosmographic speech chain structure. He invites the patient to infer that he himself was not responsible for choosing this Hadīth, indexing his contact with another realm. Responsibility for the selection of the Hadith presumably lies with some agent other than the healer himself. 


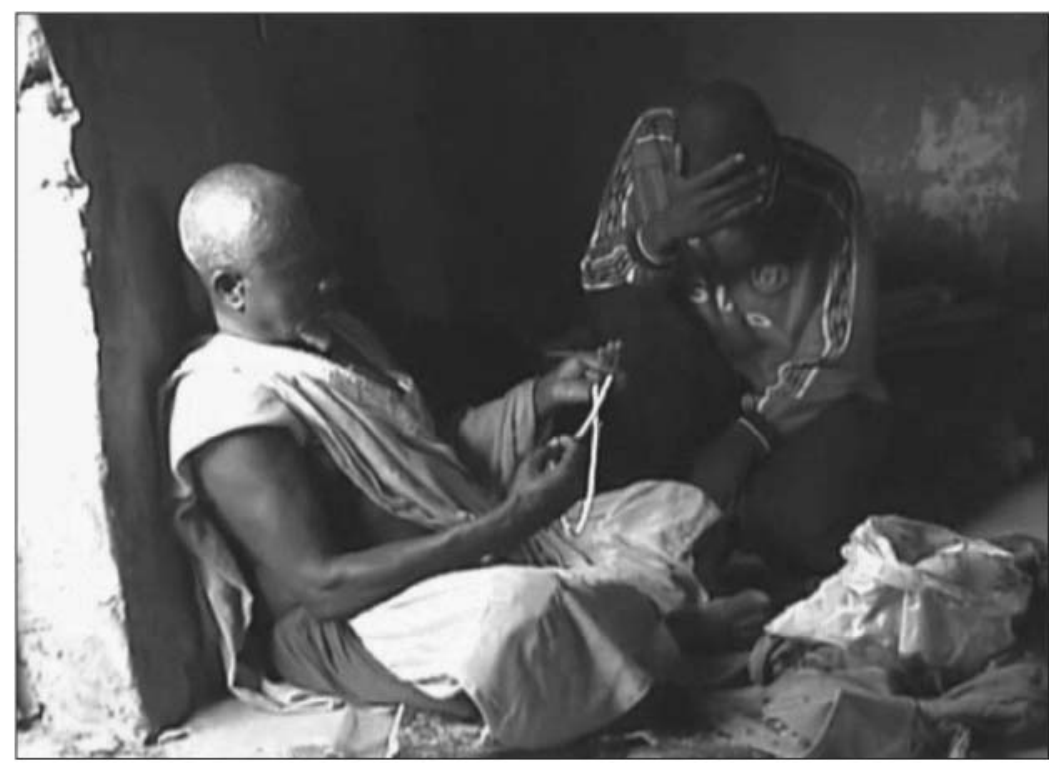

Figure 2. Sërĩn Siñañ counts prayer beads during divination phase (image extracted from original video footage)

As indicated in the synoptic chart (Table 1), during the divination phase, Sërīñ Siñaañ's son suddenly arrives, briefly disrupting the ethnomedical encounter. After his son leaves, Sërīñ Siñaañ returns his attention to the case at hand. As he resumes, he utters 'yes' (in Wolof, waaw) at line $157 \mathrm{a}$, perhaps marking a topic boundary, since he then resumes his work on the patient. The healer says 'now let's see what this means' (in Wolof, léegi ñu seet ko baxam namm demee), which implies that he is not responsible for the meaning that he finds. I would suggest that the healer, in brief, is positioning himself as a mediator in two distinct ways here: he indexes his expert knowledge and he also displaces responsibility away from self, positioning himself as a mediator who stands between the patient and incorporeal beings, which is what the divination phase is supposed to accomplish (cf. Park 1967; Bascom 1969, 1980; Turner 1975; Peek 1991).

(3) (Transcript Segment 3)

Sérīn (S)

157a S: waaw (0.79) léegi ñu seet ko baxam namm yes now we-AuX.subj see it how go demee go 'yes (0.79) now, let's see how it goes [i.e., what this means]' 
$157 b$

$$
\begin{aligned}
& \text { (0.57) waaw baax na } \\
& \text { yes good it-AUX.SUBJ } \\
& \text { '(0.57) yes, it is good' }
\end{aligned}
$$

To sum up the evidence for the second form of mediation, involving contact with a realm of incorporeal agents, Sërĩñ Siñaañ:

- cross-modally ceases communicative contact with the patient during the divination phase by re-directing his gaze away from the patient; by lowering the volume of his speech; by reciting an unintelligible incantation;

- shifts responsibility away from self by having the patient select a bead from the prayer beads; by mechanically counting back the beads; by uttering léegi ñu seet ko baxam namm demee ('let's see what this means').

This displacement of responsibility away from self together with the divination phase's cross-modal inaccessibility, helps begin to construct an interdiscursive structure of mediation, where there is a projected source beyond the here-and-now speech event, to which only the healer has access. These spirits (who may be ancestors, jinnes, or rabs), again, are believed to play an indirect but important role in healing. They are to assist Sërĩn Siñaañ in finding a cure for the patient; in this case, the spirit apparently locates the appropriate Hadith portion to recite.

\section{Healing as mediation: The textual construction of an interdiscursive speech chain}

As the event develops, Sërĩñ Siñaañ begins to construct a more elaborate mediational structure through his discourse. From lines $157 \mathrm{c}$ to line $160 \mathrm{~m}$, he begins to recite the Hadith, and he does so by parallelistically alternating between Arabic and Wolof. Each line begins with an Arabic word or phrase from the Hadith. The Arabic is then exegetically unpacked immediately afterward in Wolof. The fact that Sërĩn Siñaañ glosses the passages from the Hadith for the patient in Wolof implies a difference in relative expertise. The healer presupposes that the patient lacks both knowledge of the Arabic used in the Hadīth and knowledge of the Hadīth more generally and therefore needs Sërīñ Siñaañ to gloss it for him in Wolof. As he does elsewhere in this encounter, Sërĩñ Siñaañ thus initiates patterns that index his discursive self-positioning with respect to an authoritative, transcendent realm (for more details, see Perrino 2002). That is, he implicitly brings the patient into contact with this realm through his 
Table 2. Parallelism in code switching during section of Hadīth recitation

\begin{tabular}{|c|c|}
\hline & Arabic $\longrightarrow$ Wolof \\
\hline $157 \mathrm{j}$ & $\begin{array}{l}\text { wa ma kountoume tahmalouna ci mbir } \\
\text { wa ma kountoume tahmalouna in-CLSF-SG-PROX inside } \\
\text { 'wa ma kountoume tahmalouna as for the problem' }\end{array}$ \\
\hline $157 \mathrm{k}$ & $\begin{array}{l}\text { wa anta naka yow } \\
\text { wa anta how you-AUX.EMPH.SG } \\
\text { 'wa anta as far as you [i.e., your need is concerned]' }\end{array}$ \\
\hline 1571 & 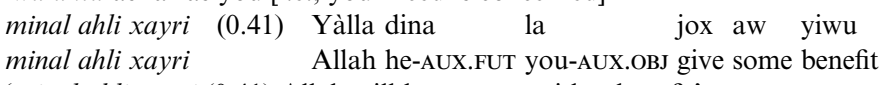 \\
\hline $157 \mathrm{~m}$ & $\begin{array}{l}\text { 'minal ahli xayri ( } 0.41) \text { Allah will honor you with a benefit' } \\
\text { wa sadatane ak téxé } \\
\text { wa sadatane and be-in-the-almighty-of-Allah } \\
\text { 'wa sadatane and he [i.e., Allah] will relieve you from your problems' }\end{array}$ \\
\hline
\end{tabular}

mediating role as exegete. But his act of glossing the Hadīth's Arabic into Wolof appears to do more than position him as more knowledgeable than the patient in terms of the arts of healing. The parallelistic code shifts and glosses from Arabic to Wolof project a figure of the transmission of discourse through the mediation of Sërĩn Siñaañ, creating the second form of mediation, the virtual, cosmographic speech-chain structure. The healer transmits Arabic discourse from the Hadīth to the patient, and as he does this, he renders it more intelligible by translating it into the local code, Wolof. Sërĩñ Siñaañ seems to position himself as a mediator who facilitates contact between the patient and the power of Allah. He constructs what, following Agha (2003), one can refer to as an interdiscursive 'speech chain' in which he plays a crucial mediating role (see Table 2 and Figure 3).

Agha defines the notion of the speech chain as 'a historical series of speech events, linked together by the permutation of individuals across speech-act roles in the following way: the receiver of the message in the (n)th speech event is the sender of the message in the $(n+1)$ th event' (2003: 247). Speech-chain structures link together individuals through activities of speaking, reading, writing, and so forth. The speech chain described here is what Agha calls a 'virtual chain', 'a representation of another utterance which is purported to have occurred' (Agha 2006: 70). This is a type of interdiscursive model, created in discourse, whose links have not been independently investigated.

In short, during the divination and recitation of Hadīth phases, Sërīn Siñaañ indexes his role as expert and simultaneously attempts to interdiscursively establish contact with incorporeal beings. In the recitation of the Hadìth phase, he presupposes that successful contact with these beings 


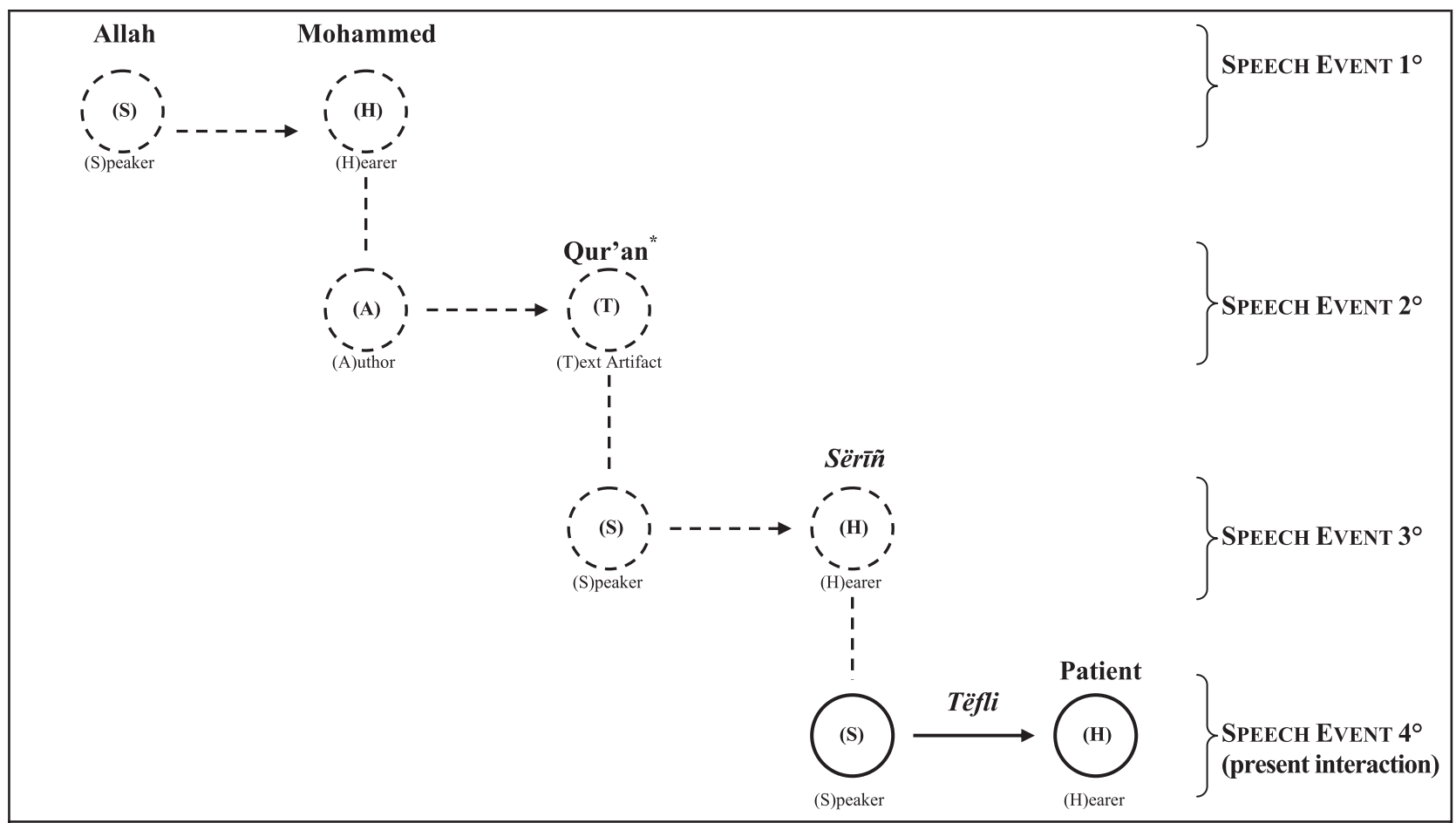

${ }^{*}$ The role permutation from the Qur'an-as-text-artifact to the Qur'an-as-speaker is achieved through the trope of personification. The numbering of the speech events $\left(1^{\circ}-4^{\circ}\right)$ indicates degrees of remove from the originary speech event between Allah and Mohammed.

Figure 3. Virtual speech-chain structure 
has been made, and he creates a virtual speech chain that includes the personnel, himself and the patient. Though not analyzed in this article, the healer occupies a mediating role in this virtual speech chain even more dramatically at the end of this event. At the end of the ritual, he casts Qur'anic saliva upon the patient (in Wolof, Tëfli [see Figure 3]), saliva which had been invested with Qur'anic verses uttered by the healer. Saliva here is believed to serve as a carrier of the Qur'anic verses that are transmitted to the patient with the help of the healer (see Perrino 2002). It becomes a semiotically palpable way of conveying blessings from a remote, spiritual source to the patient in the immediate speech event.

\section{Conclusion}

In my examination of how discourse accessibility is regulated during the real-time course of a ritual event, I have shown how it is a processual, bydegrees, phase-relative phenomenon. I have especially focused on how it involves multiple channels (not only language) and involves changes in participation structure. In terms of the processual and phase-relative qualities, the ritual specialist here regulates discourse accessibility through verbal and nonverbal means as the event develops. As Briggs has written, '... just as curers use their specialized lexicon in producing unintelligibility, they can increase the semantic accessibility ... when they choose to do so' (Briggs 1996: 206; emphasis in original). In this ethnomedical encounter, the healer adjusts discourse accessibility across phases of the encounter in several ways. He begins with close interpersonal contact with the patient, he reduces contact during the divination phase, and he then reestablishes contact as he begins to semiotically make manifest his own contact with incorporeal agents.

Besides being processual and phase-relative, changes in access involve changes in participation structure. There is an intimate connection here between the regulation of access and a mediatory participation structure. By regulating access to discourse (through semantic opaqueness of ritual formulae, decreased loudness, shifts in gaze direction, etc.), the healer implicitly distinguishes participants in terms of access to some domain of knowledge, source of agency, and so forth. That is, by obscuring a semiotic channel, he foregrounds that channel as a potential communicative barrier, a barrier that he uses, in turn, to distinguish participants from each other. In many respects, this emphasis on the way the regulation of accessibility involves changes in participation builds on Schieffelin's earlier work on emergence in ritual performance. Performance, he wrote, was to be 'sought further in the emerging relation between the performer 
and the other participants (and the participants among themselves) while the performance is in progress' (Schieffelin 1985: 722). Schieffelin's comment is taken for granted in the contemporary performance literature and in interactionalist studies, but it needs to be reconsidered in our approach to ritual unintelligibility.

In addition to involving changes in participation structure, I have suggested that the study of discourse accessibility also frequently requires a consideration of nonverbal behavior, because access is regulated in many ways. If we consider the 'multichannel architecture' (Duranti 1992: 660; LeVine and Scollon 2004; cf. Norris 2004; Norris and Jones 2005) of unintelligibility by examining the nonverbal behavior that co-occurs with opaque lexical items, for example, we may also more easily see how this multimodal sign behavior involves changes in participation and participation status (cf. Briggs 1996). Co-speech gaze-shifts, paralinguistic accompaniments, and nonverbal backchannel behavior (such as nods), for example, can serve important, reflexive functions in face-to-face interaction, as has long been well known.

In terms of what the healer accomplishes through regulating access, I suggested that he constructs two overlapping and mutually reinforcing forms of mediation, one in which he stands between the patient and expert knowledge, and the other in which he stands between the patient and incorporeal beings. In terms of the latter, the healer's verbal and nonverbal contributions, with their accompanying changes in participation structure, help project a virtual model of interdiscursivity, a relay designed to convey curative power and blessings from spiritual agents to the ailing addressee. In both cases, it is clear that discourse accessibility is not an isolated cognitive event, as the notion of '(un)intelligibility' suggests; instead, it involves changes in participation structure, through which these forms of mediation come into being.

\section{Appendix: Transcription symbols and abbreviations}

Transcription symbols have been adapted partly from the works of Jefferson (1979), Duranti (1992), Edwards and Lampert (1993), and Schiffrin (1994).

[ Overlapping utterances
$=$
Latching, or contiguous utterances, with an interval of less
than one-tenth of second between lines
Time intervals within and between utterances (length of
pauses in seconds and tenths of seconds)




\begin{tabular}{|c|c|}
\hline$::$ & Syllable lengthening \\
\hline$:: \ldots::$ & Prolonged syllable lengthening \\
\hline$\circ \circ$ & $\begin{array}{l}\text { These two symbols surround speech that is quieter than the } \\
\text { surrounding talk }\end{array}$ \\
\hline & Syllable cut-off \\
\hline & Stopping fall in tone \\
\hline$[\mathrm{abc}]$ & $\begin{array}{l}\text { Text between brackets indicates transcriber's clarifications of } \\
\text { transcript }\end{array}$ \\
\hline$[\ldots]$ & $\begin{array}{l}\text { Three dots between square brackets indicate that some mate- } \\
\text { rial of the original transcript has been omitted }\end{array}$ \\
\hline$\{\mathrm{ABC}\}$ & $\begin{array}{l}\text { The material in small capitals and inside curly brackets indi- } \\
\text { cates speech participants' kinesic behavior }\end{array}$ \\
\hline AUX & Auxiliary verb \\
\hline AUX.EMPH & Emphatic auxiliary verb \\
\hline AUX.FUT & Future auxiliary verb \\
\hline AUX.OBJ & Auxiliary verb, the person indexed by which is an object \\
\hline AUX.SUBJ & Auxiliary verb, the person indexed by which is a subject \\
\hline CLSF & Classifier stem \\
\hline CNTV & Continuative suffix \\
\hline DIST & Distal deictic stem \\
\hline NEG & Negative stem \\
\hline PL & Plural \\
\hline PROX & Proximal deictic stem \\
\hline SG & Singular \\
\hline
\end{tabular}

\section{Notes}

* An earlier version of this article was presented at the 103rd annual meeting of the American Anthropological Association, 17 December 2004, in Atlanta, GA, as part of the invited session, 'Meaningful Nonsense in Ritual Language'. I wish to thank Kristina Wirtz for her comments and for her enthusiasm in putting this session and journal issue together. I especially wish to thank two anonymous Text \& Talk reviewers for their stimulating suggestions, and I thank as well Matt Tomlinson and Michael Lempert for their comments on different drafts of this article. Any remaining mistakes are, of course, my own.

In this article, I use data collected during summer pre-dissertation research in Senegal in 2000, which was funded by the University of Pennsylvania's Department of Anthropology. Subsequent research was funded by an Africa Health Practicum award from the University of Pennsylvania, a Wenner-Gren Dissertation Fieldwork Grant (\# 6957), and a Penfield Scholarship in Diplomacy, International Affairs, and Belles Lettres.

1. In some approaches, one separates out register features by studying them outside real-time ritual events, as if registers were only to be understood as bounded repertoires of form or feature types. This type of 'repertoire' perspective (Agha 2006) has 
consequences for the understanding of ritual process, however. From this repertoire perspective, unintelligibility would appear as if it were an on-or-off phenomenon: either a register is intelligible for certain categories of social actors or it is not.

2. Sërĩn Siñaañ, the traditional healer in this encounter, tragically passed away in January 2001.

3. In this article, I use the actual names of my research assistants and informants. They agreed to be recorded and to have their names included in seminar papers, conference presentations, and publications.

4. Wolof is spoken by roughly $80 \%$ of the Senegalese population, and belongs to the Atlantic linguistic group within the Niger-Congo language phylum.

5. In terms of the event's overall organization: the encounter's first phase is the 'initial greeting' (lines 1-66 [see Table 1]), after which a phase I label 'prelude' occurs (lines 67-84); here, the patient apologizes for not having visited in a while and explains how he finally came to visit this sërĩn. As the patient speaks, the sërĩn listens and offers minimal responses. At the conclusion of this phase, at line 85, the patient reinitiates the greeting phase (typical in Senegalese greetings) by calling out the healer's last name, Siñaañ. At line 95, the patient then starts to disclose his symptoms to the sërĩñ describing two ailments: persistent stomach pain and job-related problems. After this 'disclosure of symptoms' phase (lines 95-141), the patient talks less and the healer begins to identify the ailment through the use of divination. He casts Qur'anic saliva on his prayer beads to bless them (see Perrino 2002) and asks his patient to choose one of the beads. The sërĩn then counts back until he reaches the bead the patient chose. As he does this, he tries to gain contact with incorporeal beings in an effort to diagnose the patient and identify relevant verses from the Hadīth and the Qur'an that will aid in the cure. In this diagnosis and divination phase (142-144d), the sërĩn uses unintelligible incantations to establish contact with unseen beings who can help identify the cure for the patient. Sërĩn Siñaañ finds the portion of the Hadīth that he will soon recite, which begins with the words $b a$ bu salaasa. As he begins reciting the Hadith at line 143b, he is interrupted by his younger son. After this interruption (lines 145-156), the sërĩn resumes the recitation of the Hadīth phase $(157 \mathrm{a}-160 \mathrm{~m})$. The sërĩn then starts to prepare the medical remedy, which takes around 14.5 minutes. From lines 161 to 172, the sërĩ offers the medicine to the patient, and then in the 'offering of thanks' phase (lines 173-180b), the patient thanks the sërĩ $\tilde{n}$ for his assistance and requests his help and protection.

In the last major phase of this encounter (lines 180c-184c), the sëriñ recites a Qur'anic verse, a verse that was identified during the divination phase as uniquely relevant to the patient's ailment (I learned this from a follow-up interview). At the conclusion of this verse at line 184c, the sërĩn casts Qur'anic saliva on the patient, a practice known in Wolof as Tëfli. The final phase is the farewell, in which the patient takes leave (185191) (see Table 1).

6. In terms of transcription, I first transcribed the Wolof and French data cited in this article, and I then had the transcript proofread by three Senegalese informants, Marc Ndome, Djafara Sedikhou Fofana, and Mamadou Sow. Orthographic conventions from four sources were used to transcribe Wolof: Fal et al.'s Dictionnaire Wolof-Français suivi d'un Index Français-Wolof (1990), N'Diaye's Dizionario WolofItaliano (1995), Munro and Gaye's Ay Baati Wolof: A Wolof Dictionary (1997), and Diouf's Dictionnaire Wolof: Wolof-Français, Français-Wolof (2001). Translations from Wolof into French, and from Wolof and French into English, as well the interlinear grammatical glosses, are my own. See the appendix for the transcription conventions used. 


\section{References}

Agha, A. (2003). The social life of cultural value. Language \& Communication 23: 231-273. - (2006). Language and Social Relations. Cambridge: Cambridge University Press.

Bascom, W. R. (1969). Ifa Divination: Communication between Gods and Men in West Africa. Bloomington: Indiana University Press.

-(1980). Sixteen Cowries: Yoruba Divination from Africa to the New World. Bloomington: Indiana University Press.

Briggs, C. L. (1996). The meaning of nonsense, the poetics of embodiment, and the production of power in Warao healing. In The Performance of Healing, C. Laderman and M. Roseman (eds.), 185-232. New York: Routledge.

Copans, J. (1988). Les Marabouts de L'arachide: La Confrérie Mouride et les Paysans du Sénégal. Paris: L'Harmattan.

Cruise O'Brien, D. B. (1971). Chapter 1: Islam and the Wolof states. In The Mourides of Senegal: The Political and Economic Organization of an Islamic Brotherhood, D. B. C. O'Brien (ed.), 11-36. Oxford: Clarendon Press.

Cruise O'Brien, D. B. and Coulon, C. (eds.) (1988). Charisma and Brotherhood in African Islam. Oxford: Clarendon Press.

Diouf, J. L. (2001). Dictionnaire Wolof: Wolof-Français, Français-Wolof. Tokyo: The Institute for the Study of Languages and Cultures of Asia and Africa (ILCAA), Tokyo Press.

Du Bois, J. W. (1992). Meaning without intention: Lessons from divination. In Responsibility and Evidence in Oral Discourse, J. H. Hill and J. T. Irvine (eds.), 48-71. Cambridge: Cambridge University Press.

Dupire, M. (1994). Sagesse Sereer: Essais sur la Pensée Ndut. Paris: Éditions Karthala.

Duranti, A. (1992). Language and bodies in social space: Samoan ceremonial greetings. American Anthropologist 94: 657-691.

Edwards, J. A. and Lampert, M. D. (eds.) (1993). Talking Data: Transcription and Coding in Discourse Research. Hillsdale, NJ: Lawrence Erlbaum.

Fal, A., Santos, R., and Doneux, J. L. (1990). Dictionnaire Wolof-Français Suivi d'un Index Français-Wolof. Paris: Editions Karthala.

Fassin, D. (1992). Pouvoir et Maladie en Afrique: Anthropologie Sociale dans La Banlieue de Dakar. Paris: Presses Universitaires de France.

Goffman, E. (1963). Behavior in Public Places: Notes on the Social Organization of Gatherings. New York: The Free Press.

Hanks, W. F. (1996). Exorcism and the description of participant roles. In Natural Histories of Discourse, M. Silverstein and G. Urban (eds.), 160-200. Chicago: University of Chicago Press.

Hinton, L. (1980). Vocables in Havasupai song. In Southwestern Indian Ritual Drama, C. J. Frisbie (ed.), 275-305. Albuquerque: University of New Mexico Press.

Irvine, J. T. (1982). The creation of identity in spirit mediumship and possession. In Semantic Anthropology, D. Parkin (ed.), 241-260. London: Academic Press.

Jefferson, G. (1979). A technique for inviting laughter and its subsequent acceptance/ declination. In Everyday Language: Studies in Ethnomethodology, G. Psathas (ed.), 7996. New York: Irvington.

Kalis, S. (1997). Médecine Traditionnelle, Religion et Divination chez les Seereer Siin du Sénégal: La Connaissance De La Nuit. Paris: L’Harmattan.

Kearney, M. (1977). Oral performance by Mexican spiritualists in possession trance. Journal of Latin American Lore 3 (2): 309-328.

LeVine, P. and Scollon, R. (eds.) (2004). Discourse and Technology: Multimodal Discourse Analysis. Washington, DC: Georgetown University Press. 
Malinowski, B. (1965 [1935]). Coral Gardens and Their Magic. Bloomington: Indiana University Press.

Monteil, V. (1964). L'islam Noir. Paris: Éditions du Seuil.

Munro, P. and Gaye, D. (1997). Ay Baati Wolof: A Wolof Dictionary. Los Angeles: University of California, Department of Linguistics.

N'Diaye, E. A. (1995). Dizionario Wolof-Italiano. Trieste: Scuola Superiore di Lingue Moderne per Interpreti e Traduttori, Università di Trieste.

Norris, S. (2004). Analyzing Multimodal Interaction: A Methodological Framework. New York: Routledge.

Norris, S. and Jones, R. H. (2005). Discourse in Action: Introducing Mediated Discourse Analysis. New York: Routledge.

Park, G. K. (1967). Divination and its social contexts. In Magic, Witchcraft, and Curing, J. Middleton (ed.), 233-254. Austin: University of Texas Press.

Peek, P. M. (1991). African Divination Systems: Ways of Knowing. Bloomington: Indiana University Press.

Perrino, S. M. (2002). Intimate hierarchies and Qur'anic saliva (tëfli): Textuality in a Senegalese ethnomedical encounter. Journal of Linguistic Anthropology 12 (2): 225-259.

Powers, W. K. (1986). Sacred Language: The Nature of Supernatural Discourse in Lakota. Norman: University of Oklahoma Press.

Samarin, W. J. (1972). Tongues of Men and Angels: The Religious Language of Pentecostalism. New York: The Macmillan Company.

Schieffelin, E. (1985). Performance and the cultural construction of reality. American Ethnologist 12 (4): 707-724.

Schiffrin, D. (1994). Approaches to Discourse. Cambridge: Blackwell.

Severi, C. (1993). Talking about souls: The pragmatic construction of meaning in Cuna ritual language. In Cognitive Aspects of Religious Symbolism, P. Boyer (ed.), 165-181. Cambridge, UK: Cambridge University Press.

Tambiah, S. J. (1968). The magical power of words. Man 3 (2): 175-208.

Turner, V. W. (1975). Revelation and Divination in Ndembu Ritual. Ithaca, NY: Cornell University Press.

Wilce, J. M. (2001). Divining troubles, or divining troubles? Emergent and conflictual dimensions of Bangladeshi divination. Anthropological Quarterly 74 (4): 190-200.

Wirtz, K. (2005). 'Where obscurity is a virtue': The mystique of unintelligibility in Santería ritual. Language and Communication 25 (4): 351-375.

Zempléni, A. (1966). La dimension thérapeutique du culte des rabs. Ndöp, tuuru et samp. Rites de possession chez les lebou et les wolof. Psychopathologie Africaine: Bulletin de la Société de Psychopathologie et d'Hygiène Mentale de Dakar II (3): 295-439.

- (1977). From symptom to sacrifice: The story of Khady Fall. In Case Studies in Spirit Possession, V. Crapanzano and V. Garrison (eds.), 87-139. New York: Wiley.

- (1978). La thérapie traditionnelle des troubles mentaux chez les wolofs et les lébou (Sénégal). In African Therapeutic Systems, Z. A. Ademuwagun, J. A. A. Ayoade, I. E. Harrison, and D. M. Warren (eds.), 144-150. Waltham, MA: Crossroads Press.

Sabina Perrino earned her Ph.D. in linguistic and sociocultural anthropology at the University of Pennsylvania in December 2006. She has conducted fieldwork in Senegal and among Senegalese migrants in Italy. Her research interests include discourse and narrative analysis, textuality, ethnomedicine, healer-patient communication, alternative modernities, and transnational migration. Address for correspondence: Department of Anthropology, University of Pennsylvania, 323 University Museum, 3260 South Street, Philadelphia, PA 19104-6398, USA〈perrino@sas.upenn.edu〉. 